E-ISSN : $2477-0124$
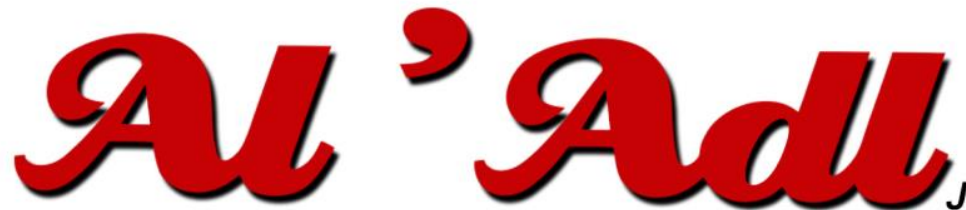

Jurnal Hukum

Editorial Office: Faculty of Law, Islamic University Of Kalimantan,

Jalan Adhyaksa No. 2 Kayutangi Banjarmasin, Kalimantan Selatan, Indonesia (70123)

Email: al_adl@uniska-bjm.ac.id

Web: http://ojs.uniska-bjm.ac.id

\section{PERBANDINGAN SISTEM HUKUM MENGENAI DISIPLIN HUKUM}

\author{
Yulianis Safrinadiya Rahman ${ }^{1}$ \\ Fakultas Hukum Universitas Islam Kalimantan MAB \\ Jl. Adhyaksa Nomor 2 Kayutangi Kota Banjarmasin \\ Email: yulianisrahman2807@gmail.com
}
Submitted
: 25 Januari 2021
Revised
: 27 Januri 2021
: 29 Januari 2021
Accepted
: 3 Februari 2021

\begin{abstract}
The state of Indonesia is a constitutional state where the actions of the government and the people are based on the law to prevent arbitrary actions. In a rule of law state, the government guarantees law enforcement to achieve legal objectives, the law has the task of creating legal certainty to achieve the goals of law and order in society. Law is an arrangement or order which is regulated from all related parts in the social system which is a unity of legal regulations. The research method used is normative juridical based on library material and secondary data as a reference taken from the literature related to the problem under study. The legal system is a unit consisting of elements that interact with each other and work together to achieve the goal of unity. Reviewing comparative law investigating or studying one legal institution from one legal system to another legal institution. By comparing the legal systems, one can find the similarities and differences between the two legal systems and find out what causes the differences. Legal discipline is a system of teachings regarding the realities or symptoms of existing laws and living in the midst of social interactions. Legal discipline is an attitude that relates to philosophy on the one hand and political teachings on the other. Thought about legal discipline is a teaching system regarding the reality or symptoms of law which is a teaching system that determines what to do in the face of reality.
\end{abstract}

Keywords : Comparison of Legal Systems, Legal Discipline.

\title{
Abstrak
}

Negara Indonesia adalah negara hukum dimana tindakan pemerintah maupun rakyatnya didasarkan atas hukum untuk mencegah adanya tindakan sewenang-wenang. Dalam suatu negara hukum, pemerintah menjamin adanya penegakan hukum untuk tercapai tujuan hukum, hukum bertugas menciptakan kepastian hukum untuk tercapainya tujuan hukum dan ketertiban dalam masyarakat. Hukum adalah suatu susunan atau tatanan yang diatur dari keseluruhan bagian yang berkaitan dalam sistem kemasyarakatan merupakan kesatuan dari peraturanperaturan hukum. Metode Penelitian yang digunakan secara yuridis normatif berdasarkan bahan Pustaka dan data sekunder sebagai acuan diambil dari literatur yang berkaitan dengan permasalahan yang diteliti. Sistem Hukum adalah suatu kesatuan yang terdiri dari unsur-unsur yang mempunyai interaksi satu sama lain dan

\footnotetext{
${ }^{1}$ Dosen Fakultas Hukum MAB
} 
bekerjasama untuk mencapai tujuan kesatuan. Mengkaji perbandingan hukum menyelidiki atau mempelajari salah satu lembaga hukum dari sistem hukum yang satu dengan lembaga hukum yang lain. Dengan membandingkan system hukum dapat ditemukan unsur persamaan dan perbedaan dari kedua sistem hukum dan ditemukan apa ebab sampai terjadi perbedaan. Disiplin hukum adalah sistem ajaran mengenai kenyataan atau gejala-gejala hukum yang ada dan hidup di tengah pergaulan masyarakat. Disiplin hukum adalah sikap yang berhubungan pada pihak yang satu dengan filsafat dan pada lain pihak dengan ajaran politik. Pemikiran tentang disipilin hukum adalah sistem ajaran mengenai kenyataan atau gejala-gejala hukum yang merupakan sistem ajaran yang menentukan apakah yang harus dilakukan didalam menghadapi kenyataan.

Kata Kunci : Comparison of Legal Systems, Legal Discipline.

\section{PENDAHULUAN}

Kehidupan bermasyarakat dan bernegara terdapat berbagai peraturan yang memaksa masyarakat untuk tunduk dan patuh pada aturan-aturan yang berlaku. Sifat ketundukan maupun kepatuhan masyarakat terhadap peraturan adalah karena adanya kesadaran hukum, yaitu memahami makna dan tujuan hukum bagi kemashlatan kehidupan bermasyarakat dan bernegara, atau karena rasa takut terhadap sanksi hukum yang akan menimpanya apabila melanggar peraturan yang berlaku sehingga mau tidak mau hukum harus dipatuhi.

Ketaatan pada hukum maupun peraturan yang berlaku memaksa masyarakat untuk senantiasa menjalani hidup dan kehidupan individual maupun sosialnya selalu berada dalam kedisiplinan dan keamanan diri, karena pelanggaran dan penyimpangan terhadap hukum pada hakikatnya merupakan kerugian bagi perjalanan kehidupan manusia sebagai individual maupun sebagai komunitas sosial. Hukum adalah himpunan petunjuk-petunjuk hidup (perintah perintah dan larangan-larangan) yang mengatur tata tertib dalam suatu masyarakat, dan oleh karena itu seharusnya ditaati oleh anggota masyarakat yang bersangkutan.",2

Sistem hukum adalah suatu susunan atau tatanan yang diatur, suatu keseluruhan yang terdiri atas bagian-bagian yang berkaitan satu sama lain, tersusun menurut suatu rencana atau pola, hasil dari suatu pemikiran, untuk mencapai suatu tujuan tertentu. Sistem kemasyarakatan tersebut mencakup bagian-bagian yang dapat disebut sebagai subsistem. ${ }^{3}$ Sistem yang merupakan kesatuan dari peraturan-peraturan hukum yang disusun secara tertib menurut asasasasnya. Sudikno Mertokusumo menyatakan Sistem Hukum adalah suatu kesatuan yang terdiri dari unsur-unsur yang mempunyai interaksi satu sama lain dan bekerjasama untuk mencapai tujuan kesatuan tersebut. Menurut Fuller, hukum barulah dapat dikatakan sebagai sistem, jika memenuhi 8 (delapan) asas yang dinamakan "Principles Of Legality", yaitu :

\footnotetext{
${ }^{2}$ Riduan Syahrani. 2011. Rangkuman Intisari Ilmu Hukum. Bandung : PT Citra Aditya Bakti. hlm.17.

${ }^{3}$ Pipin Syarifin, 1999. Pengantar Ilmu Hukum. Bandung: Pustaka Setia, hlm. 162.

${ }^{4}$ Aloysius R. Entah dan Teguh Suratman. 2017. Perbandingan Sistem Hukum. Universitas Merdeka Malang. hlm. 4-5.
} 
a. Suatu sistem hukum harus mengandung peraturan-peraturan, tidak boleh sekedar mengandung keputusan.

b. Peraturan-peraturan yang dibuat harus diumumkan.

c. Peraturan-peraturan tidak boleh ada yang berlaku surut.

d. Peraturan-peraturan harus disusun dalam susunan yang dapat dimengerti.

e. Suatu sistem hukum tidak boleh mengandung peraturan yang bertentangan satu sama lain.

f. Peraturan-peraturan tidak boleh mengandung tuntutan yang melebihi apa yang dilakukan.

g. Tidak boleh ada kebiasaan untuk sering mengubah-ubah peraturan sehingga menyebabkan orang kehilangan orientasi.

h. Harus ada kecocokan peraturan yang diundangkan dan pelaksanaannya sehari-hari.

Berbicara perbandingan hukum adalah suatu cabang pengetahuan hukum yang menggunakan metode perbandingan di dalam menyelidiki atau mempelajari salah satu lembaga hukum dari sistem hukum yang satu dengan lembaga hukum yang kurang lebih sama dengan sistem hukujm yang lain. Dengan membandingkan itu, maka dapat ditemukan unsurunsur persamaan dan perbedaan dari kedua sistem hukum yang diselidiki, serta ditemukan apa sebab-sebab sampai terjadi perbedaan. Dari cabang-cabang hukum yang dibandingkan dapat dibedakan perbedaan-perbedaan hukum perdata, pidana, Hukum Tata Negara, dan sebagainya. ${ }^{5}$ Jika bertitik tolak pada teori hukum alam, maka tujuan perbandingan hukum adalah untuk membandingkan sistem-sistem hukum guna dapat mengembangkan hukum alam itu sendiri, sehingga tampak adanya persamaan dan perbedaan.

Menurut Van Apeldoorn tujuan hukum sebagai gejala dunia atau universal dan oleh karena itu ilmu pengetahuan hukum harus dapat memahami gejala dunia tersebut dan untuk itu kita harus memahami hukum di masa lampau dan masa sekarang. Tujuan yang bersifat praktis dari perbandingan hukum adalah alat pertolongan untuk tertib masyarakat dan pembaruan pada hukum kita sendiri dan memberikan pengetahuan tentang berbagai peraturan dan pikiran hukum kepada pembentuk undang-undang dan hukum. ${ }^{6}$

Dari berbagai wacana diatas yang merupakan disiplin hukum adalah sikap yang selalu tepat janji, sehingga orang lain percaya karena modal seseorang dalam wirausaha adalah mendapat kepercayaan dari orang lain. Disiplin berasal dari bahasa latin Discere yang artinya

\footnotetext{
${ }^{5}$ Ibid. 6.

${ }^{6}$ Ibid.
} 
belajar. Disiplin asalnya dari bahasa Inggris yaitu "disciple" yang artinya pengikut atau murid. ${ }^{7}$ Menurut Ellen G White, disiplin mempunyai tujuan sebagai berikut :

a. Perintah atas diri;

b. Menaklukan kuasa kemauan;

c. Memperbaiki kebiasaan-kebiasaan;

d. Mengajarkan menghormati orang tua dan ilahi;

e. Penurutan atas dasar prinsip;

f. Menghancurkan benteng setan.

Menurut Emile Durkheim, tujuan disiplin adalah sebagai berikut :

a. Untuk mengembangkan suatu keteraturan dalam tindakan manusia;

b. Untuk memberikan sasaran tertentu sekaligus membatasi cakrawala.

c. Pengertian disiplin merupakan perasaan taat dan patut terhadap nilai-nilai yang dipercaya merupakan tanggung jawabnya. ${ }^{8}$

d. Disiplin adalah rasa taat dan patuh terhadap nilai dan menjadi tanggung jawabnya. Dengan kata lain disiplin adalah patuh terhadap peraturan atau tunduk pada pengawasan dan pengendalian. Sedangkan pendisiplinan adalah sebuah usaha yang dilaksanakan untuk menanamkan nilai atau pemaksaan supaya subjek menjadi mentaati sebuah peraturan.

e. Disiplin merupakan sikap yang selalu tepat janji, sehingga orang lain percaya karena modal seseorang dalam wirausaha adalah mendapat kepercayaan dari orang lain. Disiplin berasal dari bahasa latin Discere yang artinya belajar. Disiplin asalnya dari bahasa Inggris yaitu "disciple" yang artinya pengikut atau murid. ${ }^{9}$

Dari beberapa Pemikiran tentang disipilin hukum adalah sistem ajaran mengenai kenyataan atau gejala-gejala hukum yang ada dan "hidup" ditengah pergaulan. Apabila lebih seksama ditelaah pengertian mengenai disiplin ini, maka dapat dibedakan antara disiplin analitis dan disiplin perspektif. Disiplin analitis merupakan sistem ajaran yang menganalisa, memahami dan menjelaskan gejala-gejala yang dihadapi, contohnya sosiologi, psikologi, ekonomi dan lain-lain. Disiplin perspektif merupakan sistem-sistem ajaran yang menentukan apakah yang seyogyanya atau yang seharusnya dilakukan didalam menghadapi kenyataankenyataan tertentu, contohnya adalah hukum, filsafat dan lain-lain. ${ }^{10}$

\section{RUMUSAN MASALAH}

\footnotetext{
${ }^{7}$ Dedi Rainer. 2017. Pengertian Disiplin, Tujuan, Macam, Manfaat, Contoh Disiplin http://www.spengetahuan.com/2017/08/pengertian-disiplin-tujuan-macam-manfaat-contoh-disiplin.html. Diakses pada tanggal 15 Maret 2018.

${ }^{8}$ Kamus Besar Bahasa Indonesia.

${ }^{9}$ Dedi Rainer. Loc. Cit.

${ }^{10}$ Soedjono Dirjosisworo. 2008, Pengantar Ilmu Hukum, Jakarta : Raja Grafindo Persada. hlm. 45.
} 
Berdasarkan pemaparan yang telah dikemukakan peneliti pada latar belakang masalah diatas, maka untuk membatasi dalam penulisan ini, peneliti merumuskan beberapa permasalahan sebagai berikut :

1. Apa saja yang mencakup dalam disiplin hukum ?

2. Bagaimana para ahli filsafat Yunani mengenai masalah-masalah disiplin hukum ?

\section{METODE PENELITIAN}

Metode Penelitian yang digunakan dalam artikel ini secara yuridis normatif karena dilakukan dengan cara meneliti berdasarkan bahan Pustaka atau berdasar yang diambil dari data sekunder sebagai acuan untuk diteliti dengan cara yang diambil berdasarkan peraturanperaturan dan literatur-literatur yang berkaitan dengan permasalahan yang diteliti.

Data sekunder adalah sumber data yang diteliti serta diperoleh melalui media perantara atau secara tidak langsung diambil dari buku-buku, catatan, serta artikel yang dipublikasikan maupun yang tidak dipublikasikan secara umum. Penelitian ini diperlukan untuk memenuhi kajian ilmuhukum sesuai yang akan kita teliti.

\section{PEMBAHASAN}

\section{A. Disiplin Hukum}

Perlindungan hukum diartikan sebagai pemberian perlindungan kepada kepentingan individu yang Disiplin hukum adalah sistem ajaran mengenai kenyataan atau gejala-gejala hukum yang ada dan hidup di tengah pergaulan. Jadi jelas bahwa disiplin hukum merupakan disiplin perspektif yang berusaha menentukan apakah yang seyogyanya, seharusnya dilakukan dalam menghadapi kenyataan-kenyataan tertentu. ${ }^{11}$

Disiplin hukum secara umum dapat dibedakan antara disiplin analitis dan disiplin perspektif. Disiplin analitis merupakan sistem ajaran menganalisa, memahami, dan menjelaskan gejala-gejala yang dihadapi, contohnya sosiologi, psikologi, ekonomi, dan lainlain. Sedangkan disiplin perspektif merupakan sistem ajaran yang menentukan apakah yang seyogyanya atau seharusnya dilakukan di dalam menghadapi kenyataan-kenyataan tertentu, contohnya adalah hukum, filsafat, dan lain-lain. ${ }^{12}$ Dengan penjelasan tersebut diatas maka

\footnotetext{
87.

${ }^{11}$ Lili Rasjidi, dan B. Arief Sidharta, 1994. Filsafat Hukum. Bandung. PT. Remaja Rosda Karya, hlm.

${ }^{12}$ Pipin Syarifin. Loc.cit.
} 
telah jelas sudah bahwa disiplin hukum adalah disiplin perspektif yang telah berusaha menentukan tentang apa yang seharusnya dan patut dalam menghadapi kenyataan. Dalam hal ini maka setidak-setidaknya ruang lingkup disiplin hukum mencakup tiga hal yaitu meliputi : (1) Ilmu-ilmu hukum, (2) politik hukum, (3) filsafat hukum. ${ }^{13}$

\section{Ilmu Hukum.}

Cabang-cabang ilmu hukum dalam disiplin hukum yaitu : ilmu hukum, ilmu kaidah, ilmu pengertian, ilmu kenyataan, filsafat hukum, politik hukum. Disiplin hukum yang didasarkan pada pohon ilmu (science tree) penjabarannya sebagai berikut $:^{14}$

a. Disiplin dasar yang mencakup :

1. Filsafat Hukum, filsafat tingkah laku atau etika yang mempelajari sedalamdalamnya dari hukum yang tidak dikaji oleh ilmu hukum.

2. Sosiologi dan Antropologi hukum. Sosiologi hukum adalah suatu cabang pengetahuan hukum yang secara analisis dan empiris mempelajari hubungan timbal balik antara hukum dan gejala-gejala sosial lainnya. Sedangkan antropologi hukum adalah antara studi hukum dan antropologi terdapat suatu hubungan yang erat karena keduanya mengkaji perihal ketertiban organisasi masyarakat dan pranata-pranata pengendaliannya yang sesungguhnya merupakan kajian yang tergolong sentral, seperti masalah-masalah struktur tertib, dan fungsionalisasi setiap komponen struktur, aksi serta perilaku individu pemeran sosial dalam struktur, dan segala pengendalian yang coba diefektifkan oleh para penguasa di dalam struktur. Contohnya : untuk masyarakat sederhana, pola sengketa dan penyelesaiannya dalam bentuk putusan penguasa adat dan putusan masyarakat adat, misalnya : kawin lari, dan sebagainya.

3. Psikologi hukum, adalah suatu cabang pengetahuan yang mempelajari hukum sebagai suatu perwujudan dari jiwa manusia. Pengetahuan ini mempelajari perilaku atau sikap tindak hukum yang merupakan perwujudan dari gejala-gejala kejiwaan tertentu dan juga landasan kejiwaan dari perilaku atau sikap tindak tersebut.

4. Sejarah Hukum, yaitu salah satu bidang studi hukum yang mempelajari perkembangan dan asal usul sistem hukum dalam masyarakat tertentu dan membandingkan antara hukum yang berbeda karena dibatasi oleh waktu yang berbeda.

5. Perbandingan Hukum, adalah suatu cabang pengetahuan umum yang menggunakan metode perbandingan di dalam menyelidiki atau mempelajari salah satu lembaga hukum dari sistem hukum yang satu dengan lembaga hukum yang kurang lebih sama dengan sistem hukum yang lain.

b. Disiplin pokok yang terdiri dari :

1. Ilmu Kaidah.

2. Ilmu pengertian, yang kedua-duanya disebut juga dogmatik hukum.

\footnotetext{
${ }^{13}$ Purnadi Purbacaraka dan Soerjono Soekanto, 1982. Sendi-Sendi Ilmu Hukum dan Tata Hukum. Bandung. Alumni. hlm. 29.

${ }^{14}$ Esma Warasih. 2005. Pranata Hukum. Semarang. PT. Suryanddaru Utama. hlm. 165.
} 
c. Disiplin cabang, yang meliputi :

1. Ilmu hukum tata negara.

2. Ilmu hukum administrasi negara.

3. Ilmu hukum pribadi.

4. Ilmu hukum harta kekayaan.

5. Ilmu hukum keluarga.

6. Ilmu hukum waris.

7. Ilmu hukum pidana.

Secara garis besar ilmu hukum dapat dijelaskan sebagai berikut $:{ }^{15}$

a. Ilmu hukum adalah pengetahuan mengenai masalah yang bersifat manusiawi, pengetahuan tentang yang benar dan yang tidak benar menurut harkat kemanusiaan.

b. Ilmu yang formal tentang hukum positif.

c. Sintesa ilmiah tentang asas-asas yang pokok dari hukum.

d. Penyelidikan oleh para ahli hukum tentang norma-norma, cita-cita dan teknikteknik hukum dengan menggunakan pengetahuan yang diperoleh dari berbagai disiplin di luar hukum yang mutakhir.

e. Ilmu hukum adalah nama yang diberikan kepada suatu cara untuk mempelajari hukum, suatu penyelidikan yang bersifat abstrak, umum dan teoritis, yang berusaha mengungkapkan asas-asas yang pokok dari hukum.

f. Ilmu hukum, adalah ilmu tentang hukum dalam seginya yang paling umum. Segenap usaha untuk mengembalikan suatu kasus kepada suatu peraturan, adalah suatu kegiatan ilmu hukum, sekalipun nama yang umumnya dipakai dalam bahasa inggris dibatasi pada artiannya sebagai aturan-aturan yang paling luas dan konsep yang paling fundamental.

g. Teori ilmu hukum menyangkut pemikiran mengenal hukum atas dasar yang paling luas.

h. Suatu diskusi teoritis yang umum mengenai hukum dan asas-asas sebagai lawan dari studi mengenai peraturan-peraturan hukum yang konkrit.

i. Ia meliputi pencarian ke arah konsep-konsep yang tuntas yang mampu untuk memberikan ekspresi yang penuh arti bagi semua cabang ilmu hukum.

j. Ilmu hukum adalah pengetahuan tentang hukum dalam segala bentuk dan manifestasinya.

k. Pokok bahasa ilmu hukum adalah luas sekali meliputi hal-hal yang filsafati, sosiologis, historis maupun komponen-komponen analitis dari teori hukum.

1. Ilmu hukum berarti sikap pemikiran yang teliti dan berbobot mengenai semua tingkat kehidupan hukum, asal pemikiran itu menjangkau keluar batas pemecahan terhadap suatu problem yang konkrit, jadi ilmu hukum meliputi semua macam generalisasi yang jujur dan dipikirkan masak-masak di bidang hukum. ${ }^{16}$

Dengan berbagai pendapat tersebut, maka akan semakin jelaslah mengenai ruang lingkup yang dipelajari oleh ilmu hukum. Termasuk dalam ilmu hukum ini adalah $:{ }^{17}$

\footnotetext{
${ }^{15}$ Soedjono Dirjosisworo. Op.cit.

${ }^{16}$ Satjipto Rahardjo, 2000. Ilmu Hukum. Penerbit PT. Citra Adytia Bakti, hlm. 48.

${ }^{17}$ Ibid. hlm. 49
} 
a. Ilmu Kaidah, yaitu ilmu yang menelaah hukum sebagai kaidah atau sistem kaidah-kaidah dengan dogmatik hukum dan sistematik hukum. Disini akan dikemukakan :

1. Ruang lingkup ilmu tentang kaidah, yaitu :

a) Macam-macam kaidah, yaitu : ada tata kaidah aspek hidup pribadi (Kaidah-kaidah kepercayaan, kaidah-kaidah kesusilaan), dan tata kaidah aspek hidup antar pribadi (kaidah-kaidah sopan santun, kaidah-kaidah hukum).

b) Kaidah hukum dari sudut daya cukup maupun hirarki yang meliputi kaidah hukum abstrak atau umum dan kaidah hukum konkrit atau individual.

c) Isi dan sifat kaidah hukum yang merupakan pembahasan tentang struktur keadaan hukum yang isinya suruhan, larangan dan kebolehan, serta dapat bersifat imperatif atau fakultatif.

d) Perumusan kaidah hukum, dimana diadakan pembedaan antara pandangan hipotesis atau bersyarat, dengan pandangan kategoris atau tanpa syarat yang kedua-duanya dapat dikemukakan dalam perumusan pasal-pasal peraturan perundang-undangan.

e) Tugas kaidah hukum, yaitu pemberian kepastian hukum yang tertuju pada ketertiban, dan pemberian kesebandingan hukum yang tertuju pada ketenangan atau ketentraman.

f) Esseialia dari kaidah hukum yang berisikan pembahasan untuk menjawab pertanyaan apakah hal memaksa atau paksaan merupakan sifat dari hukum. Sifat memaksa dari kaidah hukum adalah tidak essensiil, akan tetapi sifat membatasi dan mematoki dari kaidah hukum adalah essensiil.

g) Penyimpangan terhadap kaidah hukum yang mencakup pengecualian dan penyelewengan.

h) Pernyataan kaidah hukum yang terutama membahas masalah hubungan antara pernyataan kaidah hukum dengan kaidah kebiasaan.

i) Tanda-tanda pernyataan kaidah hukum, yaitu tanda-tanda yang berwujud ( bahan-bahan resmi yang tertulis, rambu-rambu lalu lintas, benda-benda, kebiasaan), tanda-tandan yang tidak berwujud (tandatanda yang berupa bunyi suara, hikmat kata-kata yang dirumuskan secara lisan, perintah-perintah secara lisan).

j) Kelakuan kaidah hukum yang mencakup : hal yang berlakunya secara yuridis, sosiologis, dan filosofis.

2. Kaidah hukum dan kaidah lainnya

Kaidah atau norma bertujuan untuk menciptakan tata tertib dalam masyarakat. Dalam kehidupan bermasyarakat, terdapat empat macam kaidah atau norma yaitu : norma keagamaan, norma kesusilaan, norma kesopanan, norma hukum.

3. Sifat kaidah hukum. 
Barangsiapa dengan sengaja melanggar sesuatu kaidah hukum akan dikenakan sanksi yang berupa hukuman. Penyimpangan terhadap ikatan norma hukum akan membentuk kelompok manusia yang melanggar norma hukum yang harus berhadapan dengan kelompok pemimpin masyarakat yang berperan untuk menetapkan ancaman dan menerapkan sanksi sebagai reaksi norma hukum, dan berhadapan juga dengan kelompok masyarakat lainnya yang taat mempertahankan norma hukum.

4. Fungsi dan tujuan hukum.

Fungsi hukum sebagai alat ketertiban dan keteraturan masyarakat, sarana untuk mewujudkan keadilan sosial lahir bathin, sarana penggerak pembangunan, daya kerja hukum tidak semata-mata melakukan pengawasan pada aparatur penegak hukum termasuk didalamnya. Tujuan hukum adalah ketertiban masyarakat. Hukum diperlakukan untuk penghidupan di dalam masyarakat dengan kebaikan dan ketentraman bersama.

5. Berlakunya kaidah hukum.

Hukum itu harus mempunyai dasar-dasar berlakunya yang baik. Agar hukum mempunyai kekuatan berlakunya secara baik adalah mempunyai dasar yuridis, dasar filosofis, dasar sosiologis. Dalam rangka pembuatan peraturan perundang-undangan, misalnya Undang-undang, peraturan pemerintah pengganti undang-undang, peraturan pemerintah, peraturan daerah, surat keputusan, intruksi, dan sebagainya harus mengandung ketiga landasan tersebut. Karena peraturan perundang-undangan adalah hukum.

6. Ilmu Pengertian, yakni ilmu tentang pengertian-pengertian pokok dalam hukum, seperti misalnya masyarakat hukum, subyek hukum, obyek hukum, hukum obyektif, hukum subyektif, hubungan hukum, akibat hukum, peristiwa hukum, perbuatan melawan hukum, dan lain-lain.

a. Masyarakat hukum, hukum timbul dalam masyarakat, berbagai macam kepentingan slaing bertemu menyebabkan berkembangnya hukum dalam masayarakat itu. Sesuatu yang menetapkan hukum untuk dirinya sendiri dan kemudian masyarakat itu mengikatkan diri pada hukum itu, hal ini disebut masyarakat hukum. Masyarakat hukum yang terpenting adalah negara, desa.

b. Subyek hukum, ialah pendukung hak dan kewajiban, dan terdiri dari dua macam yaitu orang (person) dan badan hukum (rechtspersoon).

c. Obyek hukum (rechts obyek), ialah segala sesuatu yang berguna bagi subyek hukum (person atau rechts person), dan yang menjadi obyek 
hukum dari suatu hubungan hukum disebut hak, karena ia dapat dikuasai oleh subyek hukum.

d. Hukum obyektif, adalah pada peraturan hukum (normanya hukum) yang ditunjukan terhadap setiap orang yang berkepentingan dan yang memberikan hak jaminan perlindungan. Atau hukum dalam suatu negara yang berlaku umum dan tidak mengenal orang atau golongan tertentu. Hukum ini hanya menyebut peraturan hukum saja yang mengatur hubungan hukum antara dua orang atau lebih.

e. Hukum subyektif, adalah hak yang diberikan oleh norma tersebut. Atau hukum yang timbul dari hukum obyektif dan berlaku terhadap seorang tertentu atau lebih.

f. Hubungan hukum, adalah hubungan antara dua subyek hukum atau lebih mengenai hak dan kewajiban subyek hukum yang satu berhadapan dengan hak dan kewajiban subyek hukum yang lain.

g. Akibat hukum, adalah segala akibat yang terjadi dari segala perbuatan hukum yang dilakukan oleh subyek hukum terhadap obyek hukum atau akibat-akibat lain yang disebabkan karena kejadian-kejadian tertentu oleh hukum yang bersangkutan telah ditentukan atau dianggap sebagai akibat hukum.

h. Peristiwa hukum, adalah hubungan yang diatur oleh hukum disebut hubungan hukum isinya adalah suatu wewenang yang ada pada seseorang untuk menguasai sesuatu atau untuk menuntut sesuatu dari orang lain untuk bertingkah laku sesuai dengan wewenang yang ada. Dalam ilmu hukum, wewenang atau hak dan kewajiban tidak dapat dipisahkan. Isi hak dan kewajiban itu ditentukan oleh aturan hukum. Aturan hukum terdiri dari peristiwa dan akibat yang oleh aturan hukum tersebut dihubungkan.

i. Perbuatan melawan hukum, Pasal 1365 KUH Perdata berbunyi “ Tiap perbuatan melanggar hukum, yang membawa kerugian kepada orang lain, mewajibkan orang yang karena kesalahannya menerbitkan kerugian itu, mengganti kerugian tersebut."

7. Ilmu Kenyataan, yang menyoroti hukum sebagai perikelakuan atau sikap tindak, yang antara lain dipelajari dalam sosiologi hukum, antropologi hukum, psikologi hukum, perbandingan hukum dan sejarah hukum.

\section{Filsafat Hukum.}

Filsafat hukum adalah ilmu pengetahuan yang mempelajari pertanyaan-pertanyaan mendasar dari hukum. Atau ilmu pengetahuan tentang hakikat hukum. Dikemukakan dalam ilmu ini tentang dasar-dasar kekuatan mengikat dari hukum. ${ }^{18}$

Filsafat hukum menurut para ahli hukum sebagai berikut :

a. Purnadi Purbacaraka dan Soerjono Soekanto mengatakan bahwa filsafat hukum adalah perenungan dan perumusan nilai-nilai, juga mencakup penyerasian nilainilai misalnya : penyerasian antara ketertiban dengan ketentraman antara

\footnotetext{
${ }^{18}$ Ibid. hlm. 56
} 
kebendaan dengan keakhlakan, dan antara kelanggengan / konservatisme dengan pembaharuan.

b. Lili rasjidi, filsafat hukum adalah suatu ilmu yang merupakan bagian dari filsafat. Filsafat itu terdiri dari berbagai bagian. Salah satu bagian utamanya adalah filsafat moral, yang disebut juga etika. Obyek dari bagian utama ini ialah tingkah laku manusia dari segi baik dan buruk yang khas, yang ditemukan dalam tingkah laku manusia, yaitu baik atau buruk menurut kesusilaan. Filsafat hukum adalah bagian dari filsafat moral atau etika.

c. R. Otje Salman, filsafat hukum adalah kegiatan merenung, merumuskan dan menyerasikan nilai-nilai (konsepsi abstrak tentang hal yang baik dan hal yang buruk).

d. E Utrech/ Moh Saleh Djindang, filsafat hukum menyangkut persoalan-persoalan, adanya hukum dan tujuannya, berlakunya hukum dan keadilan.

Manfaat filsafat hukum yaitu filsafat hukum itu memperdalam dan memperluas pengetahuan tentang hukum, yang menjadi obyek hukum positif, filsafat hukum itu memiliki nilai yang sangat tinggi terutama bagi ahli hukum. Kemudian aliran-aliran filsafat hukum juga menjadi penyebab lahirnya sosiologi hukum, yaitu aliran Positivisme yang diajarkan oleh Hans Kelsen dengan Stufenbau des Recht. Bahwa hukum itu bersifat "hierarchie" artinya hukum itu tidak boleh bertentangan dengan ketentuan yang lebih atas derajatnya. ${ }^{19}$

\section{Politik Hukum.}

Politik hukum mencakup kegiatan-kegiatan memilih dan menerapkan nilai-nilai, merupakan disiplin hukum yang mengkhususkan dirinya pada usaha memerankan hukum dalam mencapai tujuan yang dicita-citakan oleh masyarakat tertentu. Politik hukum, yang menyelidiki perubahan-perubahan apa yang seharusnya diadakan terhadap hukum yang berlaku pada masa kini, sehingga lebih selaras dengan perasaan hukum yang ada pada masyarakat, dan berusaha sedapat mungkin meredakan ketegangan yang terjadi antara peraturan perundang-undangan dengan perasaan hukum masyarakat. ${ }^{20}$

Politik hukum menurut para ahli hukum sebagai berikut $:^{21}$

a. E.Utrecht / Moh Saleh Djindang, politik hukum berusaha membuat kaidah-kaidah yang akan menentukan bagaimana seharusnya manusia bertindak. Politik hukum

\footnotetext{
${ }^{19}$ Pipin Syarifin. Loc.cit.

${ }^{20}$ Abdul Latif dan Hasbi Ali. 2010. Politik Hukum. Jakarta: Sinar Grafika. Hlm. 59

${ }^{21}$ Ibid, hlm. 62
} 
meneruskan perkembangan hukum dengan berusaha melenyapkan sebanyakbanyaknya ketegangan positivitas dan realitas sosial.

b. R. Otje Salman, politik hukum yaitu kegiatan memilih dan menerapkan nilai-nilai.

c. Soedjono Dirdjosisworo, politik hakikatnya adalah sarana untuk mencapai tujuan tersebut yang untuk itu dinilai proses pemilihan tujuan. Oleh karenanya politik adalah juga aktivitas memilih tujuan tertentu.

d. Sudarto, Politik hukum adalah kebijaksanaan dari negara melalui badan-badan yang berwenang untuk menetapkan peraturan-peraturan yang dikehendaki yang diperkirakan bisa dipergunakan untuk mengespresikan apa yang terkandung dalam masyarakat dan untuk mencapai apa yang dicita-citakan.

Mengenai politik hukum Indonesia, pemerintah mempunyai tugas menyeleksi untuk menetapkan pokok-pokok pikiran dari nilai-nilai hukum yang terdapat dalam masyarakat dan merumuskan peraturan-peraturannya melalui badan yang berwenang. Sesudah itu pemerintah masih memikirkan tentang daya guna dan hasil guna peraturan yang dibuat itu, agar dapat mencapai cita-cita ketentraman, ketertiban dan kesejahteraan bagi masyarakat. $^{22}$

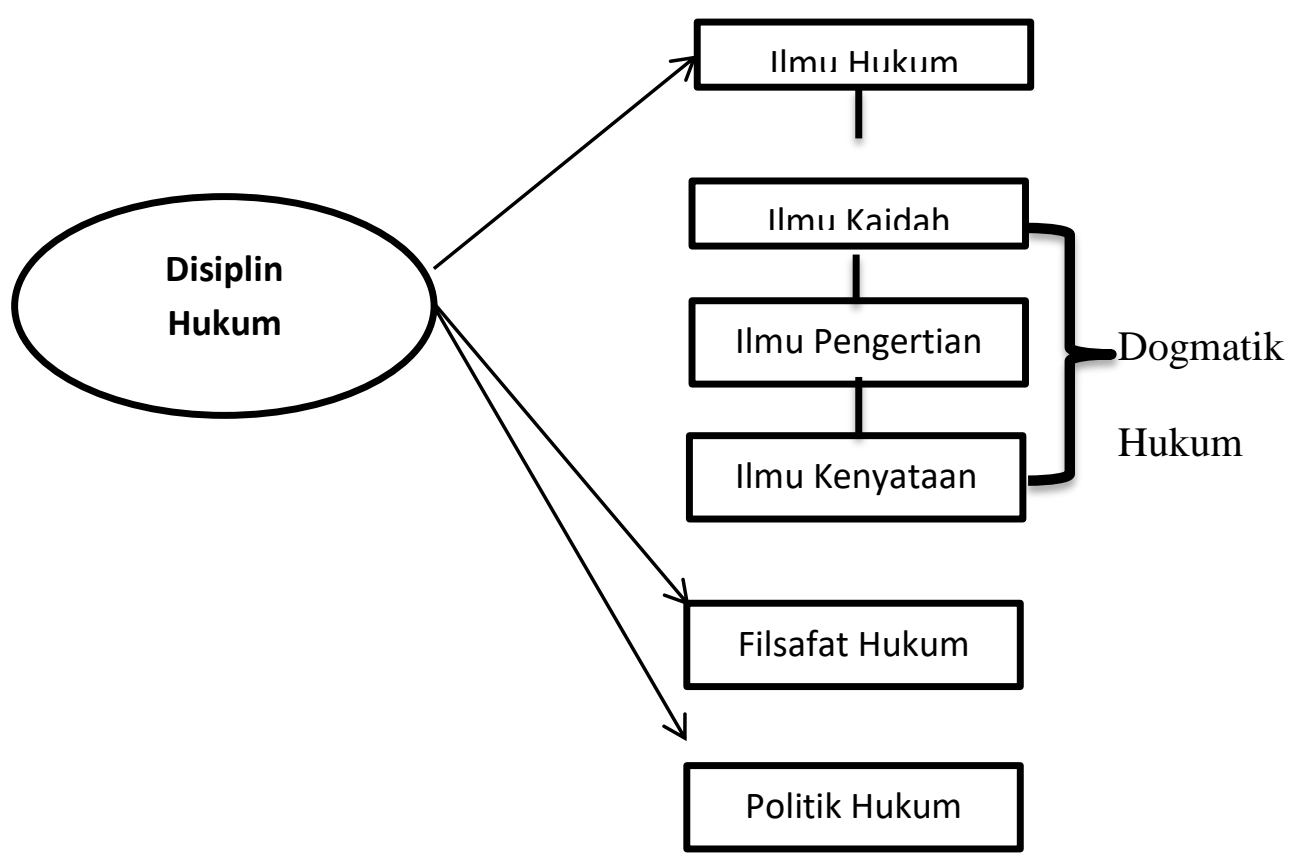

\section{A. Para Ahli Filsafat Yunani Mengenai Masalah-masalah Disiplin Hukum.}

\section{Pendapat Homerus}

Hukum mendapat kedudukan yang penting, tetapi tanpa permasalahan. Hukum terjelma dalam Themistes yang diterima oleh para raja dari Dewa Zeus, sebagai

\footnotetext{
${ }^{22}$ Ibid. hlm 6
} 
sumber kudus/sakral segala keadilan duniawi yang berdasarkan adat dan tradisi. Keadilan adalah masih sama dengan ketertiban (order) dan kewibawaan (authority). Kesadaran mengenai konflik antara hukum positif dan keadilan menjadi makin jelas mulai abad ke-8 dan seterusnya. Latar belakangnya adalah kekacauan sosial, ketidak puasan terhadap aristokrasi dan meningkatnya, penyalahgunaan kekuasaan. Masalah tentang hubungan antara keadilan dan hukum positif menguasai alam pikiran Yunani, sebagaimana pada hakekatnya semua renungan hukum semenjak masa itu. Para ahli filsafat alam dari mazhab Milesia berpaling kearah alam luar manusia sebagai sumber hukum yang lebih langgeng daripada hukum buatan manusia. Proses penemuan hukum alam dalam irama kejadian-kejadian oleh Heraclitus dan para ahli filsafat kemudian, membawa pada konsepsi tentang alam yang bertentangan dengan akal. ${ }^{23}$

Perkembangan ini membawa para ahli filsafat Yunani pada suatu pandangan tentang hubungan antar dunia semesta diluar manusia dan dunia didalam bathin manusia. Dalam fase pertama, tema terpenting merupakan antitesa tragis antara perlunya mentaati hukum positif negara dan tuntutan kesusilaan yang lebih tinggi dari hukum suci yang tidak tertulis serta tidak berubah. Ungkapannya yang klasik terdapat dalam drama Aeschylus dan Sophocles : baik "Eumenides" ciptaan Aeschylus maupun "Antigone" ciptaan Sophocles berakhir dengan seruan untuk mentaati hukum sebagai penjamin ketertiban, kedamaian dan keserasian dalam negara. Keduanya masih dikuasai oleh kesadaran tentang apa yang diwujudkan sebelum kemunduran demokrasi Athena, suatu kepercayaan kepada kemajuan yang diperoleh dari suatu masyarakat yang berperadaban dan tertib yang dikuasai oleh hukum yang bijaksana, sebagai pengganti dari kekacauan dan kelalaian zaman sebelumnya.

\section{Pendapat Plato.}

Menghadapi kebobrokan masyarakat Athena dan keambrukan nilai-nilai dan hasil-hasil yang dipuji oleh Pericles, keduanya membaktikan sebagian besar dari hasil karya mereka untuk mencapai definisi yang lebih konkrit tentang keadilan serta hubungan antara keadilan dan hukum positif. Tetapi seperti telah dikatakan oleh Hans Kelsen mereka mendekati masalah itu dari dua sudut yang berlainan, yang dipertentangkan olehnya sebagai pendekatan metafisis dan pendekatan rasionel. ${ }^{24}$

\footnotetext{
${ }^{23}$ Purnadi Purbacaraka dan M. Chaidir. 1990. Disiplin Hukum. Bandung : Citra Aditya Bakti. hlm 6

${ }^{24}$ Ibid. hlm. 8
} 
Plato mencoba menjabarkan konsepsi/gagasannya tentang keadilan dari ilham, Aristoteles memperolehnya dari analisa ilmiah berdasarkan prinsip-prinsip rasionel yang diperkembangkan terhadap suatu latar belakang berbagai-bagai jenis masyarakat politik dan hukum yang memang terdapat pada masa itu. Mata rantai yang menghubungkan mereka berdua adalah konsepnya tentang kebijakan, yaitu gagasan yang meliputi segala sesuatu yang keadilan merupakan bagian dan aspek yang mutlak. Keserasian adalah menurut Plato suatu keadaan keseimbangan bathin yang tak mungkin dianalisa dengan akal. Pernyataan yang paling jelas mengenai konflik antara keadilan dan legalitas diberikan dalam suatu percakapan singkat, yang bilamana tidak dengan pasti diadakan oleh Plato sendiri, sekurang-kurangnya dibuat oleh salah seorang pengikutnya. Dalam "Minos", Socrates dan seorang murid membahas definisi tentang hukum dan mereka bergerak dari definisi asli tentang hukum, sebagai suatu yang ditentukan dalam bentuk yang tepat oleh penguasa yang bewenang, kearah keharusan untuk menghubungkan hukum dengan pengungkapan kebenaran dan kebaikan.

\section{Pendapat Aristoteles.}

Disiplin hukum adalah lebih tegas karena ia mendapat ilhamnya setelah mempelajari dengan mendalam tentang hukum dan konstitusi yang ada (secara ensiklopedis). ${ }^{25}$

Doktrin Aristoteles yang paling asasi adalah apa yang sejak itu mengilhami bukan saja disiplin hukum tetapi pula filsafat barat pada umumnya, adalah sifat ganda tabiat manusia sebagai bagian dari dan sebagai penguasa alam. Sebagai bagian dari alam semesta, manusia itu takluk kepada hukum jasmaniah dan segenap penciptaanNya, tetapi sekaligus pula manusia itu menguasai alam dengan akalnya, yang memberikan kemauan/kehendak bebas kepadanya dan memungkinkannya untuk membedakan apa yang baik dari yang jahat.

Pandangan Aristoteles kepada renungan hukum adalah perumusannya tentang masalah keadilan. Pembedaannya antara keadilan yang "distributif" (memberi bagian) dan "korektif" (mengadakan perbaikan) atau "remedial" (memberikan pengobatan) masih tetap merupakan dasar segala diskusi mengenai persoalan ini : ${ }^{26}$

\footnotetext{
${ }^{25}$ Ibid. hlm 11.

${ }^{26}$ Ibid. hlm. 12.
} 
a) Keadilan yang distributif, mengatur pembagian barang-barang dan penghargaan kepada tiap orang sesuai dengan kedudukannya dalam masyarakat, serta menghendaki perlakuan yang sama bagi mereka yang berkedudukan sama menurut hukum.

b) Bentuk keadilan korektif adalah terutama merupakan suatu ukuran dari prinsip-prinsip teknis yang menguasai administrasi daripada hukum (pelaksanaan undang-undang). Dalam mengatur hubungan hukum perlu ditemukan ukuran umum untuk menanggulangi akibat-akibat perbuatan, tanpa memandang siapa orangnya dan maksudnya harus dapat dinilai menurut suatu ukuran obyektif hukuman harus memperbaiki kejahatan, ganti rugi harus memperbaiki kesalahan / penyelewengan perdata, pengembalian harus memperbaiki keuntungan yang diperoleh dengan tidak wajar.

Pendapat Aristoteles pembedaan antara keadilan menurut undang-undang dan keadilan alam (kodrat) atau lebih jelas bagi kita, antara hukum positif dan hukum alam. Yang pertama mendapat kekuatannya dari penetapan sebagai hukum, entah adil atau tidak adil, hal itu menjelaskan sebabnya ada bermacam-macam hukum positif. Yang kedua (hukum alam) mendapat kekuatannya dari apa yang didasarkan pada tabiat manusia dimana saja dan kapan saja. ${ }^{27}$

Pembedaannya antara keadilan yang abstrak (abstract justice) dan equity. Hukum dengan sendirinya bersifat umum dan seringkali ketat (keras/kejam), bilamana dilaksanakan terhadap sesuatu perkara yang khusus. Equity dapat mengubah dan memperlunak ketaatan dalam mempertimbangkan perkara yang khusus tersebut.

Definisi tentang hukum, sebagai suatu kumpulan peraturan yang mengikat, baik pejabat-pejabat maupun rakyat. Hukum berbeda dari ketentuan-ketentuan yang mengatur dan mengungkapkan bentuk konstitusi, adalah peranan hukum untuk membimbing tingkah laku para pejabat dalam melaksanakan tugasnya dan untuk menghukum para pelanggar. ${ }^{28}$ Aristoteles menekankan keadilan yang legal atau positif yang lebih diutamakan dari pada prinsip kebaikan abadi manapun.

\section{PENUTUP}

Disiplin hukum adalah sistem ajaran mengenai kenyataan atau gejala-gejala hukum yang ada dan hidup di tengah pergaulan masyarakat. Disiplin hukum adalah sikap yang berhubungan dengan filsafat dan ajaran politik. Disiplin hukum mencakup tiga hal yaitu meliputi : (1) Ilmu-ilmu hukum, (2) politik hukum, dan (3) filsafat hukum. Pemikiran para

\footnotetext{
${ }^{27}$ Ibid. hlm. 15.

${ }^{28}$ Ibid. hlm 14.
} 
ahli filsafat yunani tentang masalah-masalah disipilin hukum mengenai masalah-masalah tentang sistem ajaran yang berkenaan dengan tragedi dan konflik dalam menghadapi kenyataan. Perkembangan ini membawa para ahli filsafat Yunani pada suatu pandangan tentang hubungan antar dunia semesta diluar manusia dan dunia didalam bathin manusia.

\section{Buku}

\section{DAFTAR PUSTAKA}

Aloysius R. Entah dan Teguh Suratman (2017). Perbandingan Sistem Hukum. Universitas Merdeka Malang.

Esma Warasih (2005). Pranata Hukum. Semarang. PT. Suryanddaru Utama

Kamus Besar Bahasa Indonesia.

Lili Rasjidi, dan B. Arief Sidharta (1994). Filsafat Hukum. Bandung. PT. Remaja Rosda Karya

Pipin Syarifin (1999). Pengantar Ilmu Hukum. Bandung : Pustaka Setia.

Purnadi Purbacaraka dan Soerjono Soekanto (1982). Sendi-sendi Ilmu Hukum dan tata Hukum. Bandung. Alumni.

Purnadi Purbacaraka dan M. Chidir (1990). Disiplin Hukum. Bandung : Citra Aditya Bakti.

Riduan Syahrani (2011). Rangkuman Intisari Ilmu Hukum. Bandung : PT Citra Aditya Bakti.

Soedjono Dirjosisworo (2008). Pengantar Ilmu Hukum. Jakarta : Raja Grafindo Persada.

Satjipto Rahardjo (2000). Ilmu Hukum. Penerbit PT. Citra Aditya Bakti.

\section{Jurnal}

Efa Laela Fakhriah, "Eksistensi Small Claim Court dalam Mewujudkan Tercapainya Peradilan Sederhana, Cepat, dan Biaya Ringan”, Bandung: UNPAD, 2014.

Jamin Ginting, "Sistem Peradilan di Indonesia", Jurnal Law Review, Volume Nomor 2, November 2007.

Xandra Kramer, The European Small Claims Procedure: Striking the Balance between Simplicity and Fairness in European Litigation, Zeitschrift für europäisches Privatrecht, No. 2. 


\section{Internet}

Aan Nurhasanah. 2015. Makalah Pengantar Ilmu Hukum. http://duniahukumblogaddress.blogspot.co.id/2015/09/makalah-pengantar-ilmuhukum.html. Diakses pada tanggal 14/03/2018.

https://www.apaarti.com/perbandingan.html. Pengertian Perbandingan. Diakses pada tanggal $14 / 03 / 2018$.

Dedi Rainer. 2017. Pengertian Disiplin, Tujuan, Macam, Manfaat, Contoh Disiplin http://www.spengetahuan.com/2017/08/pengertian-disiplin-tujuan-macammanfaat-contoh-disiplin.html. Diakses pada tanggal 15 Maret 2018.

Ensikloblogia. Pengertian Perbandingan Hukum, serta Tujuan dan Manfaat PerbandinganHukum.http://www.ensikloblogia.com/2016/11/pengertianperbandingan-hukum-serta.html. Diakses pada tanggal 15 Maret 2018. 